\title{
CONHECIMENTO E EDUCAÇÃO NA PÓS-MODERNIDADE
}

\author{
Helena Damião* \\ João Manuel Ribeiro**
}

Resumo: Este texto tem como objetivo apontar como as tentativas pósmodernas de negarem a verdade do valor intrínseco do conhecimento produzem um conjunto de conseqüências negativas para o processo educativo.

Palavras-chave: pós-modernismo, conhecimento, processo educativo. 


\section{Introdução}

A tradição metafísica ocidental oferece, no dizer de Searle (1999), um conjunto de princípios básicos que nos permitem sustentar o valor e a verdade do conhecimento contra as tentativas pós-modernas de os desvalorizar e, mesmo, de os negar. Assim, é necessário sustentar que a realidade existe independentemente das representações humanas, contra a perspectiva de que tudo são representações da realidade. Como tal, a realidade é sempre e só a realidade apreendida e/ou construída pelo sujeito.

É preciso também reconhecer que a linguagem possibilita a comunicação ao nível do significado e não apenas ao nível do significante, isto é, o que se comunica tem por norma uma relação com objetos e estados de coisas, cuja existência é independente da linguagem e até do emissor e do receptor da mesma. É preciso reclamar, ainda, que aquilo que designamos por verdade procura traduzir com precisão as representações: "as afirmações procuram descrever como são as coisas no mundo, cuja existência é independente da afirmação, e a afirmação será verdadeira ou falsa em função delas no mundo serem realmente como ela diz que são"(SEARLE, 1999, p. 10). Deste conjunto de princípios, o referido autor retira uma conclusão, o nosso ver, fundamental para inferir o valor do conhecimento: "os padrões intelectuais [...] são critérios de excelência e realização intelectuais objectiva e inter-subjectivamente válidos" (SEARLE, 1999, p. 15).

Não nos cumpre, nesta reflexão, discutir todos os aspectos implicados nesta conclusão, mas não podemos deixar de afirmar que negar a verdade do valor intrínseco do conhecimento produz um conjunto de consequências educativas susbstanciais, entre as quais destacamos as seguintes (v.g. CASTILLO, 1992; DENNETT, 1993; LIPOVETSKY, 1988; NOZICK, 1981; SEARLE, 1999):

- a educação formal tende a tornar-se medíocre e, de algum modo, paradoxal, porque tudo vale e nada vale; porque tudo é verdade e nada é verdade;

- o valor do conhecimento não se afere segundo citérios gnoseológicos e de verificabilidade, suscitadora de argumentação e de provas, mas obedece a critérios de ordem emocional e vivencial;

- deixa de se considerar o valor intrínseco do conhecimento para 
sobrevalorizar o seu valor instrumental, ou seja, só se ensina e só se aprende o que tem utilidade imediata e interesse para e no quotidiano dos sujeitos;

- o conhecimento com características universalizantes e abstracto é desvalorizado face a conhecimentos regionais e concretos, relativos ao contexto social, cultural, étnico dos sujeitos; - a complexidade torna-se o paradigma educativo fundamental, com a inerente opacidade de linguagem, de âmbitos e de finalidades;

- é elogiada a espontaneidade supostamente criadora, não directiva, ao ritmo do bem-estar dos alunos, com o risco da dispersão em detrimento da concentração, do temporário em vez do voluntário;

- a intencionalidade educativa desloca-se para a periferia da vocação escolar e, sobretudo, põe-se ao serviço das dinâmicas sociais culturais e económicas;

- opera-se uma transferência do domínio das idéias, da razão, da objectividade para o das experiências significativas, com o conseqüiente discurso parcial e despretensioso assente numa matriz intimista, narcisista, subjectivista;

- a apresentação dos conteúdos, para serem aceites e reconhecidos, têm de se apresentar de forma inovadora, mediática, agradável e significativa para os alunos, confundindo-se, assim, o pensamento com o lúdico;

- a escola vê-se obrigada a "inter-agir" com as tendências e modos de organização social vigentes, ganhando sentido em função das respostas que encontra face às exigências da economia e do mercado de trabalho;

- a pedagogia é eminentemente inter e multicultural, numa tentativa de articular os processos educativos com uma sociedade marcada pela pluralidade radical de modelos, de opções de vida individuais e grupais;

- as metodologias são de matriz sócio-construtivista, etnológica, regionalista, não sendo determinadas pela investigação disponível sobre a validade das mesmas, nem pelo educador, mas pelo educando enquadrado sempre no seu contexto social, cultural e geográfico.

Neste panorama, cria-se um círculo vicioso entre o conhecimento e a educação, que empobrece tanto um como outro, pois o conhecimento:

- deixa de ser um conhecimento a longo prazo, para o futuro, para ser um conhecimento imediato, para as questões e problemas do presente;

- aparece fragmentado, desarticulado e pouco sistemático, porque não se centra na procura dos fundamentos, mas na tecnologia e na práxis e, 
ainda, porque se centra na mudança e na inovação e, como tal, é variado, multifocal e polissémico;

- centra-se nos educandos e na individualidade de cada, nos seus gostos e interesses, perdendo o seu caráter totalizante e inserindo-se apenas e só na esfera do pessoal;

- não precisa ser fundamentado, basta que seja reconhecido como útil e empático, não se aceitando o pensamento como da ordem da razão mas, antes, da ordem da emoção.

Solicitado para publicação e autorizado pela autora em junho/2008

\section{Referências}

SEARLE, J. R. (1999). Racionalidade e realismo. Disputatio, 7, 3-25.

CASTILLO, E. G. (1992). Postmodernidad: valores y educación. Filosofía de la educación hoy - axilogía y educación. In: Actas del Congreso Internacional de Filosofía de la Educación (pp. 349-371). Madrid: UNED.

DENNETT, D. C. (1993). Fé na Verdade. Disputatio, 3, 1-19.

LIPOVETSKY, G. (1988). A era do vazio. Ensaios sobre o individualismo contemporâneo. Lisboa: Relógio d'Água.

NOZICK, R. (1981). Philosophical Explanations. London: Clarendon Press.

\section{Abstract: \\ KNOWLEDGE AND EDUCATION IN POST-MODERNISM}

This text has as its objective to point how the post-modern attempts to deny the truth of the intrinsic value of knowledge produce a set of negative consequences to the educative process. 
Keywords: post-modernism; knowledge; educative process.

Recebido em outubrode 2007.

Aceito em fevereiro de 2008 
HELENA DAMIÃO / JOÃO MANUEL RIBEIRO

Revista Pedagógica - UNOCHAPECÓ - Ano 10 - n. 20 - jan./jun.. 2008 